OPEN ACCESS

\title{
Kinetics of the solvent-mediated transformation of hydromagnesite into magnesite at different temperatures
}

\author{
F. Di Lorenzo*, R. M. Rodríguez-Galán And M. Prieto \\ Department of Geology, University of Oviedo, Oviedo, Spain
}

[Received 4 May 2014; Accepted 15 September 2014; Associate Editor T. Stawski]

\section{ABSTRACT}

The process of transforming hydromagnesite to magnesite is analysed in the context of the theory of solvent-mediated transformations. A series of experiments at 120,150 and $180^{\circ} \mathrm{C}$ with different heating times was designed to determine, by powder X-ray diffraction, the amount of magnesite generated as a function of time. The aqueous-phase composition was monitored by inductively coupled plasma-mass spectrometry and carbonate alkalimetry. From the analytical data, the evolution of saturation indexes with respect to both phases was determined using the geochemical code PHREEQC. Finally, two different methods were applied to obtain the activation energy of the process and a TTT (TemperatureTransformation-Time) graph was constructed to define suitable conditions in which to obtain magnesite.

KEYWORDS: alkalimetry, hydromagnesite, magnesite, solvent-mediated transformation.

\section{Introduction}

GLOBAL warming is an important issue worldwide and different possible remediation approaches are currently being discussed and developed. Among these approaches, geological storage of $\mathrm{CO}_{2}$ offers promise. The European Union is promoting significant advancements in this field, e.g. test injections of $\mathrm{CO}_{2}$, fully dissolved in water, into basaltic rocks (Matter et al., 2011; Gislason and Oelkers, 2014). The long-term stability of geological storage depends on the degree to which reactions between $\mathrm{CO}_{2}$, rocks and fluids are advantageous or detrimental (Oelkers and Gislason, 2010). One of the most important processes during the injection of $\mathrm{CO}_{2}$ into geological formations is the carbonation of $(\mathrm{Mg}, \mathrm{Fe}, \mathrm{Ca})$-silicates to give mineral phases such as magnesite $-\mathrm{MgCO}_{3}$, calcite $-\mathrm{CaCO}_{3}$, siderite $-\mathrm{FeCO}_{3}$, dolomite - $\mathrm{CaMg}\left(\mathrm{CO}_{3}\right)_{2}$ and carbonate solid solutions. Improving our understanding of the mineralization behaviour of anhydrous magnesium carbonates is a challenge

* E-mail: fulvio@geol.uniovi.es

DOI: 10.1180/minmag.2014.078.6.02 related to the so-called "dolomite problem" (Weber, 1964; Ardvison and Mackenzie, 1999; Mackenzie and Andersson, 2013). Several studies (e.g. Sayles and Fyfe, 1973; Königsberger et al., 1999; Pokrovsky and Schott, 1999; Urosevic et al., 2012) have shown that it is impossible to precipitate anhydrous magnesium carbonate (magnesite) and this is attributed to the large dehydration energy associated with six molecules of $\mathrm{H}_{2} \mathrm{O}$ that constitute the solvation sphere of the aqueous $\mathrm{Mg}^{2+}$ ions. Because $\mathrm{Mg}^{2+}$ is smaller than $\mathrm{Ca}^{2+}$ and $\mathrm{Fe}^{2+}$, the charge density is greater in $\mathrm{Mg}^{2+}$ and the water molecules are more closely bound. The high-energy barrier that keeps the solvation molecules bound, does not allow for precipitation of magnesite at room temperature but favours crystallization of a series of hydrated carbonates and hydroxycarbonates (Pokrovsky et al., 1999; Hänchen et al., 2008; Saldi et al., 2009; Bénézeth et al., 2011) barringtonite

This paper is published as part of a special issue in Mineralogical Magazine, Vol. 78(6), 2014 entitled 'Mineral-fluid interactions: scaling, surface reactivity and natural systems'. 
$\mathrm{MgCO}_{3} \cdot 2 \mathrm{H}_{2} \mathrm{O}$, nesquehonite $\mathrm{MgCO}_{3} \cdot 3 \mathrm{H}_{2} \mathrm{O}$, lansfordite $\mathrm{MgCO}_{3} \cdot 5 \mathrm{H}_{2} \mathrm{O}$, hydromagnesite $\mathrm{Mg}_{5}\left(\mathrm{CO}_{3}\right)_{4}(\mathrm{OH})_{2} \cdot 4 \mathrm{H}_{2} \mathrm{O}$, dypingite $\mathrm{Mg}_{5}\left(\mathrm{CO}_{3}\right)_{4}(\mathrm{OH})_{2} \cdot 5 \mathrm{H}_{2} \mathrm{O}$, and artinite $\mathrm{Mg}_{2} \mathrm{CO}_{3}(\mathrm{OH})_{2} \cdot 3 \mathrm{H}_{2} \mathrm{O}$. Recent studies of nonaqueous solvents (Xu et al., 2013) reconsider this hypothesis and indicate a strained accommodation of the $\mathrm{CO}_{3}$ group in the rhombohedral magnesite scheme that could inhibit the nucleation of magnesite at low temperatures.

The present study deals with the solventmediated transformation (Cardew and Davey, 1985) of hydromagnesite to magnesite during heating cycles over a range of temperature $\left(120-180^{\circ} \mathrm{C}\right)$ in excess of the boiling point of water. For the three temperatures under investigation $\left(120,150\right.$ and $\left.180^{\circ} \mathrm{C}\right)$ the transformation of hydromagnesite to magnesite (Sandengen et al., 2008; Xing et al., 2010) is analysed by applying the Avrami theory to isothermal solvent-mediated processes (Prigiobbe and Mazzotti, 2013). The transformation kinetics and the activation energy of the process are estimated using the so-called "time to a given fraction" method (Putnis, 1992). Moreover, the experimental data are used to construct a Temperature-Transformation-Time (TTT) graph.

\section{Methods and materials}

The experiments were performed by mixing $104.6 \mathrm{~g}$ of a 0.225 molal $\mathrm{MgCl}_{2}$ solution and $102.4 \mathrm{~g}$ of a 0.228 molal $\mathrm{Na}_{2} \mathrm{CO}_{3}$ solution. Analytical-grade chemicals (Panreac) and ultrapure water (MilliQ) were used in both cases. The two solutions were mixed in a PTFE (Polytetrafluoroethylene) vessel with a total volume of $304 \mathrm{ml}$ and a diameter $\varnothing_{\text {vessel }}=$ $6.4 \mathrm{~cm}$. Finally, $28 \mathrm{~g}$ of ultrapure water was added to the reaction vessel in order to obtain a volumefilling factor of $75 \%$ and a total, initial concentration of the reactants $[\mathrm{Mg}]_{\mathrm{T}}=[\mathrm{C}(\mathrm{IV})]_{\mathrm{T}}$ $\approx 0.1 \mathrm{~mol} / \mathrm{kgw}$. The PTFE vessel was then inserted into a stainless steel high-pressure reactor (Berghof, BR-300) and placed in a heating block. The reactor is equipped with a temperature controller (Berghof, BDL-3000), a precision manometer, and magnetic stirring (impeller diameter $\varnothing_{\text {imp }}=5 \mathrm{~cm}$ ).

The reactor was heated and kept at the target temperature under continuous stirring $(250 \mathrm{rpm})$ for defined periods of time. The two first columns (temperature and time) in Table 1 summarize the experiments performed. The experimental pres- sure is not displayed but was measured to be 9,4 and 2 bars for 180,150 and $120^{\circ} \mathrm{C}$, respectively. After the corresponding reaction period, both heating and stirring were switched off, the solutions were extracted from the reactor, filtered ( $=0.45 \mu \mathrm{m}$, Pall Corporation), and analysed for magnesium (inductively coupled plasma-mass spectrometry - ICP-MS; HP 7500c Agilent), carbonate alkalinity (Crison Compact Titrator) and $\mathrm{pH}$. The solid precipitates were dried at $30^{\circ} \mathrm{C}$ and characterized by powder X-ray diffraction (PXRD) (PANalytical X'Pert Pro) and scanning electron microscopy (SEM) imaging (JEOL6610LV). The proportion (wt.\%) of the different phases obtained in each precipitate was determined using the Rietveld quantitative-analysis tool implemented in the program X'Pert HighScore Plus version 1.0 (PANalytical). Speciation and saturation indices of the aqueous solutions were calculated from the analytical data using the geochemical code PHREEQC version 3.1.2.8538 (Parkhurst and Appelo, 2013).

\section{Results and discussion}

\section{Experimental results}

Figure 1 shows the typical diffraction patterns obtained for pure hydromagnesite, magnesite and a mixture of both phases (50 wt.\%) obtained at different reaction times in the $180^{\circ} \mathrm{C}$ series. The coexistence of both phases in the same precipitate is shown in the SEM image in Figure 1, where the typical rhombohedral shape of the magnesite crystals $(\varnothing \approx 10 \mu \mathrm{m})$ can be observed. The evolution is similar in all of the series but the kinetics increase with running temperature. Although the initial precipitate formed at room temperature is a mixture of hydromagnesite and minor amounts of other Mg-carbonate hydrates, when the target temperature is reached, only hydromagnesite remains. During the reaction process no minerals other than magnesite and hydromagnesite were detected. The experimental data are compiled in Table 1, which displays as a function of the reaction time: (1) the wt.\% of magnesite (Mgs) and hydromagnesite (Hmgs) in the precipitate; (2) the total aqueous concentration of magnesium $[\mathrm{Mg}]_{\mathrm{T}}$; (3) the amount of magnesium precipitated $\mathrm{Mg} \downarrow$, and the molar fraction of magnesite. Note that all these compositions were measured after each heating cycle, when the system was back to $25^{\circ} \mathrm{C}$.

Note that the amount of magnesite (Mgs, moles) in the precipitate increases significantly 
TABLE 1 . Summary of experimental results.

\begin{tabular}{|c|c|c|c|c|c|c|c|c|c|}
\hline Temp & $\begin{array}{l}\text { Time } \\
(\min )\end{array}$ & $\begin{array}{c}\text { Mgs } \\
\text { (wt.\%) }\end{array}$ & $\begin{array}{l}\text { Hmgs } \\
\text { (wt.\%) }\end{array}$ & $\begin{array}{c}{[\mathrm{Mg}]_{\mathrm{T}}} \\
(\mathrm{mol} / \mathrm{kg} \mathrm{w}) \\
\pm 3.16 \mathrm{E}-04\end{array}$ & $\begin{array}{c}\mathrm{Mg} \downarrow \\
(\mathrm{mol})\end{array}$ & $\begin{array}{l}\text { Mgs } \\
(\mathrm{mol})\end{array}$ & $\begin{array}{l}\text { Hmgs } \\
(\mathrm{mol})\end{array}$ & $\begin{array}{c}\text { Mgs } \\
\text { (mole } \\
\text { fraction) }\end{array}$ & $\begin{array}{c}\text { Alk } \\
(\mathrm{mol} / \mathrm{kg} \mathrm{w}) \\
\pm 1.80 \mathrm{E}-05\end{array}$ \\
\hline \multirow{9}{*}{$180^{\circ} \mathrm{C}$} & 120 & 0 & 100 & $1.92 \mathrm{E}-02$ & $1.84 \mathrm{E}-02$ & 0 & $3.68 \mathrm{E}-03$ & 0 & $3.57 \mathrm{E}-02$ \\
\hline & 130 & 0 & 100 & $1.88 \mathrm{E}-02$ & $1.85 \mathrm{E}-02$ & 0 & $3.70 \mathrm{E}-03$ & 0 & $3.51 \mathrm{E}-02$ \\
\hline & 150 & 3.3 & 96.7 & $2.05 \mathrm{E}-02$ & $1.81 \mathrm{E}-02$ & 6.61E-04 & 3.49E-03 & 0.159 & 3.49E-02 \\
\hline & 160 & 11.2 & 88.8 & $1.61 \mathrm{E}-02$ & $1.91 \mathrm{E}-02$ & $2.35 \mathrm{E}-03$ & $3.36 \mathrm{E}-03$ & 0.412 & $2.94 \mathrm{E}-02$ \\
\hline & 200 & 50.6 & 49.4 & $1.13 \mathrm{E}-02$ & $2.02 \mathrm{E}-02$ & $1.08 \mathrm{E}-02$ & $1.89 \mathrm{E}-03$ & 0.850 & $1.91 \mathrm{E}-02$ \\
\hline & 280 & 77.8 & 22.2 & 7.44E-03 & $2.11 \mathrm{E}-02$ & $1.68 \mathrm{E}-02$ & 8.64E-04 & 0.951 & $1.30 \mathrm{E}-02$ \\
\hline & 400 & 96.9 & 3.1 & $3.43 \mathrm{E}-03$ & $2.20 \mathrm{E}-02$ & 2.14E-02 & $1.23 \mathrm{E}-04$ & 0.994 & $4.56 \mathrm{E}-03$ \\
\hline & 1530 & 99.2 & 0.8 & $1.86 \mathrm{E}-03$ & 2.24E-02 & 2.22E-02 & 3.23E-05 & 0.999 & $1.94 \mathrm{E}-03$ \\
\hline & 2970 & 100 & 0 & $1.85 \mathrm{E}-03$ & $2.24 \mathrm{E}-02$ & $2.24 \mathrm{E}-02$ & 0 & 1 & 2.04E-03 \\
\hline \multirow{8}{*}{$150^{\circ} \mathrm{C}$} & 290 & 0 & 100 & $1.26 \mathrm{E}-02$ & 1.99E-02 & 0 & $3.98 \mathrm{E}-03$ & 0 & $2.28 \mathrm{E}-02$ \\
\hline & 390 & 0 & 100 & $1.88 \mathrm{E}-02$ & $1.85 \mathrm{E}-02$ & 0 & $3.70 \mathrm{E}-03$ & 0 & $3.49 \mathrm{E}-02$ \\
\hline & 700 & 0.3 & 99.7 & $1.54 \mathrm{E}-02$ & $1.93 \mathrm{E}-02$ & $6.42 \mathrm{E}-05$ & $3.84 \mathrm{E}-03$ & 0.016 & $2.75 \mathrm{E}-02$ \\
\hline & 850 & 4.5 & 95.5 & $1.98 \mathrm{E}-02$ & $1.83 \mathrm{E}-02$ & $9.09 \mathrm{E}-04$ & $3.48 \mathrm{E}-03$ & 0.207 & $2.45 \mathrm{E}-02$ \\
\hline & 1000 & 10.5 & 89.5 & $1.53 \mathrm{E}-02$ & $1.93 \mathrm{E}-02$ & $2.22 \mathrm{E}-03$ & $3.42 \mathrm{E}-03$ & 0.394 & $2.61 \mathrm{E}-02$ \\
\hline & 1530 & 81.2 & 18.8 & $1.59 \mathrm{E}-03$ & 2.24E-02 & $1.86 \mathrm{E}-02$ & 7.75E-04 & 0.960 & $1.73 \mathrm{E}-03$ \\
\hline & 2970 & 99.2 & 0.8 & $8.06 \mathrm{E}-03$ & $2.10 \mathrm{E}-02$ & $2.08 \mathrm{E}-02$ & 3.03E-05 & 0.999 & $1.28 \mathrm{E}-02$ \\
\hline & 14490 & 99.5 & 0.5 & $1.73 \mathrm{E}-03$ & 2.24E-02 & 2.23E-02 & $2.02 \mathrm{E}-05$ & 0.999 & $1.34 \mathrm{E}-03$ \\
\hline \multirow{6}{*}{$120^{\circ} \mathrm{C}$} & 390 & 0 & 100 & $2.10 \mathrm{E}-02$ & $1.80 \mathrm{E}-02$ & 0 & $3.60 \mathrm{E}-03$ & 0 & $2.50 \mathrm{E}-02$ \\
\hline & 890 & 0 & 100 & $1.96 \mathrm{E}-02$ & $1.83 \mathrm{E}-02$ & 0 & $3.67 \mathrm{E}-03$ & 0 & $3.52 \mathrm{E}-02$ \\
\hline & 4400 & 0.1 & 99.9 & $1.20 \mathrm{E}-02$ & $2.01 \mathrm{E}-02$ & $2.23 \mathrm{E}-05$ & $4.01 \mathrm{E}-03$ & 0.006 & $2.12 \mathrm{E}-02$ \\
\hline & 6500 & 6.4 & 93.6 & $1.27 \mathrm{E}-02$ & $1.99 \mathrm{E}-02$ & $1.40 \mathrm{E}-03$ & $3.70 \mathrm{E}-03$ & 0.275 & 2.31E-02 \\
\hline & 7725 & 20.2 & 79.8 & $1.31 \mathrm{E}-02$ & $1.98 \mathrm{E}-02$ & 4.34E-03 & $3.09 \mathrm{E}-03$ & 0.584 & $2.27 \mathrm{E}-02$ \\
\hline & 14490 & 98.1 & 1.9 & $1.40 \mathrm{E}-03$ & $2.25 \mathrm{E}-02$ & $2.21 \mathrm{E}-02$ & $7.72 \mathrm{E}-05$ & 0.997 & $1.65 \mathrm{E}-03$ \\
\hline
\end{tabular}

as the reaction proceeds. Such an increase correlates with a decrease in the amount of hydromagnesite (Hmgs, moles) and demonstrates the probable coupling between both processes. During the process the total amount of dissolved magnesium $[\mathrm{Mg}]_{\mathrm{T}}$ decreases by one order of magnitude, which is a consequence of the lower solubility of magnesite in comparison to hydromagnesite at the working temperatures. There is a transfer of magnesium from the aqueous to the
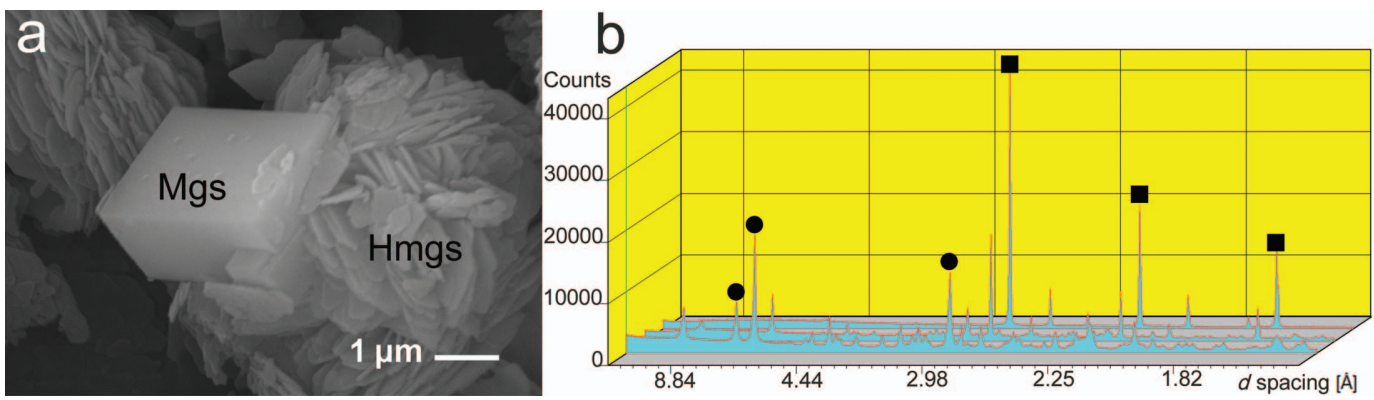

FIG. 1. (a) SEM image of magnesite and hydromagnesite at: $T=180^{\circ} \mathrm{C}, t=160 \mathrm{~min}$. (b) Schematic representation of the powder-XRD identification of the transformation process. $\square$ : most intense reflections of magnesite $-2.74 \AA$ (104), $2.10 \AA$ (113), $1.69 \AA$ (108). 0 : most intense reflections of hydromagnesite $-9.21 \AA(100), 5.80 \AA(011), 2.90 \AA(12 \overline{2})$.

The XRD patterns correspond to 120,200 and $2970 \mathrm{~min}$ of reaction time, respectively, from front to rear. 
solid phase and, therefore, the total amount of magnesium precipitated $(\mathrm{Mg} \downarrow)$ increases as time goes by. The decrease in alkalinity is concomitant as both the total inorganic carbon (TIC) and the proportion of dissociated $\mathrm{H}_{2} \mathrm{CO}_{3}$ can be expected to decrease during precipitation of carbonates in a closed reactor. Figure 2 shows the evolution of the saturation indices (SI) with respect to both phases (see next section) in the case of the $180^{\circ} \mathrm{C}$ series. Both indices decrease during the precipitationaging process. However, whereas magnesite slowly approaches equilibrium $(\mathrm{SI}=0)$ from positive values, the saturation index with respect to hydromagnesite becomes negative. Clearly the progress of the reaction involves hydromagnesite dissolution and magnesite growth until the system reaches equilibrium with the stable, magnesite phase.

\section{Hydrodynamics in the reaction vessel}

Note that not only dissolution and precipitation but also mass-transfer occur during the process. The mass-transfer effectiveness is related to the formation of a boundary layer in the vicinity of the mineral-fluid interface, where a concentration gradient develops. As a consequence, the saturation index at the surface of the precipitate particles may differ from the bulk value determined using PHREEQC. The thickness $\left(\delta_{\mathrm{c}}\right)$ of the concentration boundary layer depends on the thickness $\left(\delta_{\mathrm{H}}\right)$ of a hydrodynamic boundary layer, which in turn depends on the stirring rate:

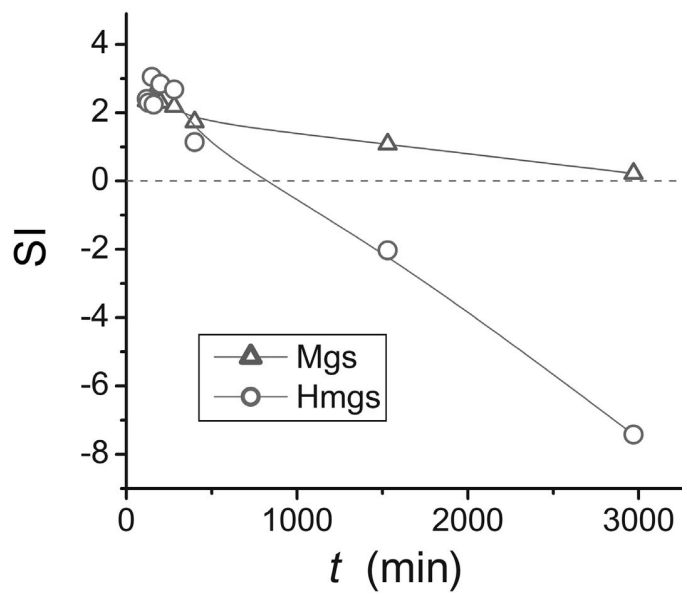

FIG. 2. Saturation index as a function of time calculated using PHREEQC from experimental data obtained in the $180^{\circ} \mathrm{C}$ series. the higher the stirring rate, the smaller the values of $\delta_{\mathrm{H}}$ and $\delta_{\mathrm{c}}$. The growth (or dissolution) rate increases with stirring speed until a certain level. Above that level, further increases in stirring have no effect on the growth or dissolution kinetics because the process is no longer controlled by mass-transfer but by (integration/release) surface processes (e.g. Prieto et al., 1996 and references therein). An estimate of the 'boundary-layer resistance' can be achieved using transport parameters and empirical equations. The main factor is the "minimum impeller speed" (Mullin, 2001), which is the minimum rotational speed required $\left(R_{\mathrm{Sm}}\right)$ to keep all the particles of a given size in suspension. There are several (more or less satisfactory) empirical equations to estimate such a limiting value. For a stirred vessel we can use the expression (Mullin, 2001):

$$
\begin{aligned}
& R_{\mathrm{sm}}= \\
& \left(\frac{\varnothing_{\text {vessel }}}{\varnothing_{\text {imp }}}\right)^{1.3}\left[v^{0.1} \varnothing_{\mathrm{p}}^{0.2} X^{0.13} \varnothing_{\text {imp }}^{-0.85}\left(\frac{g \Delta \rho}{\rho}\right)^{0.45}\right]
\end{aligned}
$$

where $g$ is acceleration due to gravity, $\varnothing_{\text {vessel }}$ and $\varnothing_{\text {imp }}$ the vessel and impeller diameters, respectively, and $\varnothing_{\mathrm{P}}$ the particle size. The rest of the symbols in equation 1 are defined in Table 2. The values correspond to the beginning of the experiments, when only hydromagnesite had been detected in the precipitates (see Table 1). The calculation was performed considering a typical particle size of $10 \mu \mathrm{m}$. In all cases, the minimum impeller speed $\left(R_{\mathrm{Sm}} \approx 50 \mathrm{rpm}\right)$ is significantly lower than rotational speed $\left(R_{\mathrm{S}}=\right.$ $250 \mathrm{rpm})$ in the reactor. Even considering magnesite (slightly denser) particles with sizes of $30 \mu \mathrm{m}$ (the largest size have observed in the present experiments), the minimum impeller speed takes values of $\sim 65 \mathrm{rpm}$, well below the stirring speed. This means that during the reaction all particles were in suspension in direct contact with the aqueous solution (no sediment in the vessel bottom). Because the suspended particles move along with the fluid in the reaction vessel an important factor for mass-transfer calculations is the "slip velocity", i.e. the relative velocity between the particle and the fluid (Mullin, 2001). This quantity is known to be proportional to both $R_{\mathrm{S}} / R_{\mathrm{Sm}}$ and inversely proportional to $\varnothing_{\mathrm{P}}$ but it is not easy to predict. In any case, the hydrodynamic boundary layer for a particle of $\sim 10 \mu \mathrm{m}$ can be expected to be in the micrometric range and the concentration boundary layer would 
TABLE 2. Hydrodynamic parameters in the reaction vessel.

\begin{tabular}{|c|c|c|c|c|c|}
\hline Symbol & Parameter & $\begin{array}{c}180^{\circ} \mathrm{C} \\
120 \mathrm{~min}\end{array}$ & $\begin{array}{c}150^{\circ} \mathrm{C} \\
290 \mathrm{~min}\end{array}$ & $\begin{array}{c}120^{\circ} \mathrm{C} \\
390 \mathrm{~min}\end{array}$ & Units \\
\hline$\rho$ & Solution density $^{1}$ & 898.2 & 927.0 & 953.4 & $\mathrm{~kg} / \mathrm{m}^{3}$ \\
\hline$\mu$ & Dynamic viscosity $^{2}$ & $7.06 \mathrm{E}-3$ & $8.43 \mathrm{E}-03$ & $1.2 \mathrm{E}-02$ & $\mathrm{~Pa} \cdot \mathrm{s}$ \\
\hline$v=\mu / \rho$ & Kinematic viscosity & $7.86 \mathrm{E}-06$ & $9.09 \mathrm{E}-06$ & $1.25 \mathrm{E}-05$ & $\mathrm{~m}^{2} / \mathrm{s}$ \\
\hline$\Delta \rho$ & $\rho_{\text {solid }}-\rho_{\text {fluid }}$ & $1.34 \mathrm{E} 03$ & $1.31 \mathrm{E} 03$ & $1.28 \mathrm{E} 03$ & $\mathrm{~kg} / \mathrm{m}^{3}$ \\
\hline$V_{1}$ & Solution volume ${ }^{3}$ & $2.60 \mathrm{E}-04$ & $2.52 \mathrm{E}-04$ & $2.45 \mathrm{E}-04$ & $\mathrm{~m}^{3}$ \\
\hline$V_{\mathrm{s}}$ & Solid volume $^{4}$ & $7.70 \mathrm{E}-07$ & 8.32E-07 & $7.53 \mathrm{E}-07$ & $\mathrm{~m}^{3}$ \\
\hline$X$ & $\begin{array}{l}\text { Volume } \\
\text { solid fraction }\end{array}$ & $2.95 \mathrm{E}-03$ & $3.29 \mathrm{E}-03$ & $3.06 \mathrm{E}-03$ & - \\
\hline$R_{S m}$ & $\begin{array}{l}\text { Minimum stirring } \\
\text { speed }\end{array}$ & 51.0 & 51.3 & 51.3 & $\mathrm{rpm}$ \\
\hline
\end{tabular}

${ }^{1}$ Calculated using PHREEQC from the experimental data in Table 1.

${ }^{2}$ Calculated from PHREEQC output data using an empirical formula (Jorgensen, 1989).

${ }^{3}$ Calculated using PHREEQC from the experimental data in Table 1.

${ }^{4}$ Calculated from the experimental data in Table 1.

be one order of magnitude thinner, according to the classical expression (Mullin, 2001):

$$
\frac{\delta_{\mathrm{H}}}{\delta_{\mathrm{c}}}=\left(\frac{v}{D}\right)^{\frac{1}{3}} \approx 9.5
$$

where $D$ is the solute diffusion coefficient $\left(\sim 10^{-8} \mathrm{~m}^{2} / \mathrm{s}\right.$ at $\left.180^{\circ} \mathrm{C}\right)$. All these estimates seem to indicate that mass transfer might have an influence on the kinetics, particularly at the beginning of the experiments when the main process is the dissolution of $\sim 10 \mu \mathrm{m}$ hydromagnesite particles kept in suspension.

\section{Thermodynamics}

According to the LLNL.DAT database (Wolery, 1992), the dissolution equilibria of hydromagnesite and magnesite at $25^{\circ} \mathrm{C}$ are given by:

$$
\begin{aligned}
& \mathrm{Mg}_{5}\left(\mathrm{CO}_{3}\right)_{4}(\mathrm{OH})_{2} \cdot 4 \mathrm{H}_{2} \mathrm{O}_{(\mathrm{s})}+6 \mathrm{H}_{(\mathrm{aq})}^{+} \leftrightarrow \\
& 5 \mathrm{Mg}_{(\mathrm{aq})}^{2+}+4 \mathrm{HCO}_{3}^{-}(\mathrm{aq}) \\
& +6 \mathrm{H}_{2} \mathrm{O}_{(\mathrm{l})} \log \mathrm{K}_{\mathrm{Hmgs}}=30.85
\end{aligned}
$$

$\mathrm{MgCO}_{3(\mathrm{~s})}+\mathrm{H}_{(\mathrm{aq})}^{+} \leftrightarrow$

$$
\mathrm{Mg}_{(\mathrm{aq})}^{2+}+\mathrm{HCO}_{3}^{-}(\mathrm{aq}) \log \mathrm{K}_{\mathrm{Mgs}}=2.29
$$

where $\mathrm{K}_{\mathrm{Hmgs}}$ and $\mathrm{K}_{\mathrm{Mgs}}$ are the corresponding equilibrium constants. Using the dissociation expressions for the solubility products, these constants correlate with $\mathrm{K}_{\mathrm{sp}}(\mathrm{Hmgs}) \approx 10^{-38.7}$ and $\mathrm{K}_{\mathrm{sp}}(\mathrm{Mgs}) \approx 10^{-8.06}$, respectively. The LLNL database includes analytical expressions that allow calculation of equilibrium constants as a function of temperature. Here, we have incorporated both equilibria in PHREEQC.DAT, the default database of PHREEQC (Parkhurst and Appelo, 2013). Despite the lack of solubility data for magnesite and hydromagnesite, PHREEQC.DAT is considered to be more self-consistent and has been used in our speciation calculations. The results obtained using other databases such as MINTEQ.V4.DAT (Allison et al., 1991) are somewhat different. The disparity in the published thermodynamic data of numerous species is due to the disparity of both the experimental measurements and the extrapolations made from the same original data (Oelkers et al., 2009). There are some recent, reliable measurements of the solubility of magnesite at different temperatures (Bénézeth et al., 2011). However, given the lack of similar measurements for hydromagnesite, we use the constants in equations 3 and 4 for the sake of consistency.

At the beginning of the experiment the aqueous solution is supersaturated with respect to both phases (see Fig. 2). Note that although the saturation index with respect to magnesite is smaller than the saturation index with respect to hydromagnesite, the solubility of magnesite is lower than the solubility of hydromagnesite $\left(S_{ \pm}\right.$ $(\mathrm{Mgs})=K_{\mathrm{sp}}^{1 / 2}(\mathrm{Mgs}) \approx 9.38 \times 10^{-5}$ and $S_{ \pm}(\mathrm{Hmgs})$ $\left.=K_{\mathrm{sp}}^{1 / 11}(\mathrm{Hmgs}) \approx 3.12 \times 10^{-4}\right)$.

In fact, magnesite is the stable phase throughout the temperature range studied. As 
shown in Fig. 3, an aqueous solution at equilibrium with magnesite is undersaturated (SI $<0$ ) with respect to hydromagnesite. However, in the initial solution, hydromagnesite precipitates metastably, which can be explained by its lower degree of dehydration. The precipitation of hydromagnesite continues until nucleation of magnesite occurs. At high temperature there is more chance of the Mg-solvation energy barrier being surpassed and the probability of nucleation of the anhydrous carbonate increases. When magnesite nucleation occurs the metastable hydromagnesite phase is near equilibrium with the aqueous solution, which is still supersaturated with respect to magnesite. Nucleation and growth of magnesite further decreases the activity of the aqueous $\mathrm{Mg}^{2+}$ ions and the solution becomes undersaturated with respect to hydromagnesite, which starts to dissolve. As a result, the metastable phase transforms into the stable phase through a dissolution-crystallization process.

For a given (non-equilibrium) composition of the aqueous solution, the free-energy change for the dissolution of one mole of hydromagnesite (according to equation 3 ) is given by:

$$
\Delta G_{\text {dis }}(\mathrm{Hmgs})=\mathrm{R} T \ln \frac{\left\{\mathrm{Mg}^{2+}\right\}^{5}\left\{\mathrm{HCO}_{3}^{-}\right\}^{4}\left\{\mathrm{H}^{+}\right\}^{-6}}{K_{\mathrm{Hmgs}}}
$$

where the terms in curly brackets represent the activities of the corresponding aqueous ions. Similarly, the free-energy change for the precipitation of one mole of magnesite can be written as follows:

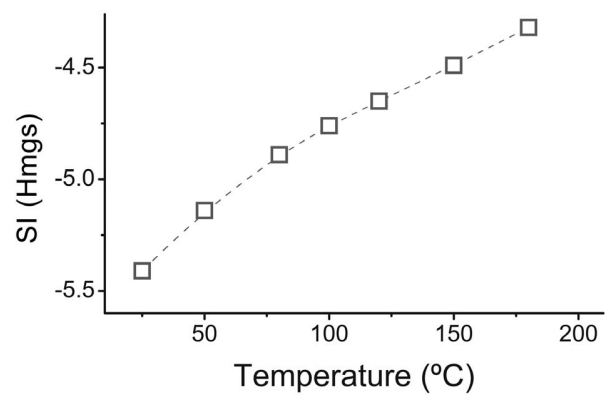

FIG. 3. Saturation index of hydromagnesite in an aqueous solution saturated with respect to magnesite at different temperatures.
$\Delta G_{\mathrm{ppt}}(\mathrm{Hmgs})=\mathrm{R} T \ln \frac{\left\{\mathrm{H}^{+}\right\}\left\{\mathrm{HCO}_{3}^{-}\right\}^{-1}\left\{\mathrm{Mg}^{2+}\right\}^{-1}}{1 / K_{\mathrm{Mgs}}}$

Finally, combining reactions 1 and 2, one arrives at the free-energy change involved in the dissolution of one mole of hydromagnesite and the subsequent precipitation of four moles of magnesite:

$\Delta G_{\text {transf }}=$

$4 \Delta G_{\mathrm{ppt}}(\mathrm{Mgs}) \cdot\left\{\mathrm{Mg}^{2+}\right\}+\Delta G_{\mathrm{dis}}(\mathrm{Hmgs})$

Equation 7 represents the driving force for the solvent-mediated transformation of one mole of hydromagnesite to magnesite. For example, for the aqueous-solution composition obtained after 280 min of reaction a $180^{\circ} \mathrm{C}, \Delta G_{\text {transf }} \approx$ $-244.2 \mathrm{~kJ} \cdot \mathrm{mol}^{-1}$, which illustrates the strong tendency of hydromagnesite to transform to magnesite at that temperature.

\section{Kinetics}

The experiments described in Table 1 allow calculation of the rate constants at 120,150 and $180^{\circ} \mathrm{C}$. Figure 4 shows the mole fraction of magnesite in the precipitates as a function of time $(t)$ at the three temperatures. The molar fraction of magnesite can be equated with $Y_{\mathrm{Mgs}}$, the fraction transformed. The data can be fitted to an Avramitype equation, as follows:

$$
Y_{\mathrm{Mgs}}=1-e^{[-\mathrm{k}(t-\tau)]^{n}}
$$

where $\mathrm{k}$ is the rate constant and $n$ a parameter that is considered to depend on the mechanism of transformation (e.g. Putnis, 1992). The third fitting parameter, $\tau$, has been introduced ad hoc in the present study as a normalization factor for time in order to discount an 'unproductive' period related to the initial heating to the target temperature. The data fit reasonably well to equation 8 . The fitting parameters are shown in Table 3. The fitting curve

TABLE 3. Fitting parameters of the experimental data to Avrami's equation.

\begin{tabular}{lcl}
\hline Temperature $\left({ }^{\circ} \mathrm{C}\right)$ & $\mathrm{k}\left(\mathrm{min}^{-1}\right)$ & \multicolumn{1}{c}{$n$} \\
\hline $180^{\circ} \mathrm{C}$ & $3.61 \mathrm{E}-2 \pm 3.5 \mathrm{E}-3$ & $1.0 \pm 0.12$ \\
$150^{\circ} \mathrm{C}$ & $1.77 \mathrm{E}-3 \pm 1.9 \mathrm{E}-4$ & $2.14 \pm 0.29$ \\
$120^{\circ} \mathrm{C}$ & $2.43 \mathrm{E}-4 \pm 9.7 \mathrm{E}-6$ & $2.67 \pm 0.14$
\end{tabular}




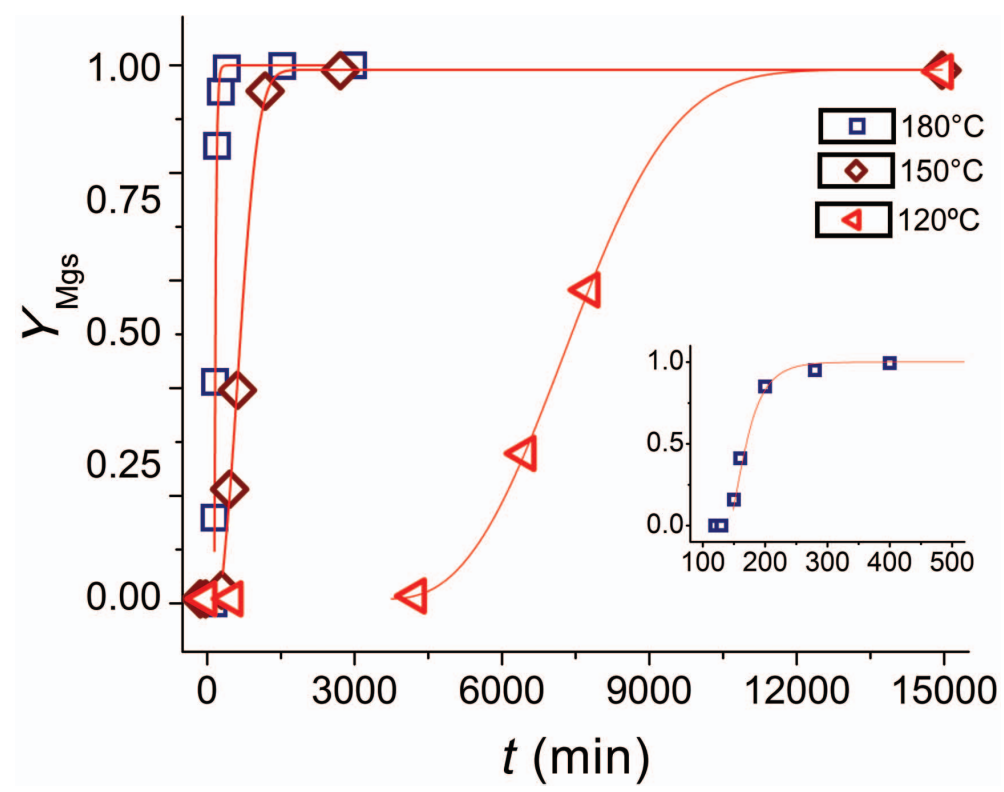

FIG. 4. Fitting of the experimental points to the Avrami equation for the three working temperatures.

has a sigmoidal form, the rate increasing to a maximum, and finally decreasing to zero as the transformation goes to completion. The Avrami equation is used frequently to fit experimental data of nucleation and growth processes (Lasaga, 1998). The values obtained for the rate constant at the different temperatures are typically used to obtain the activation energy $\left(E_{\mathrm{a}}\right)$ of the process. With this aim, the natural logarithm of the rate constant (lnk) is plotted on the ordinate $v s$. inverse temperature $\left(1 / T\right.$, Kelvin $\left.^{-1}\right)$ on the abscissa. Accepting that

$$
\mathrm{k}=\text { const. } \cdot e^{\left(\frac{-E_{\mathrm{a}}}{\mathrm{R} T}\right)}
$$

the slope of this linear Arrhenius plot is considered to correspond to the activation energy divided by the gas constant, R $\left(8.314 \mathrm{~J} \cdot \mathrm{K}^{-1} \cdot \mathrm{mol}^{-1}\right)$. Figure $5 a$ shows a linear fitting of the $\mathrm{k}$ data determined here. From the slope, an 'activation' energy of $122.6 \mathrm{~kJ} \cdot \mathrm{mol}^{-1}$ has been obtained. However, as Lasaga (1998)
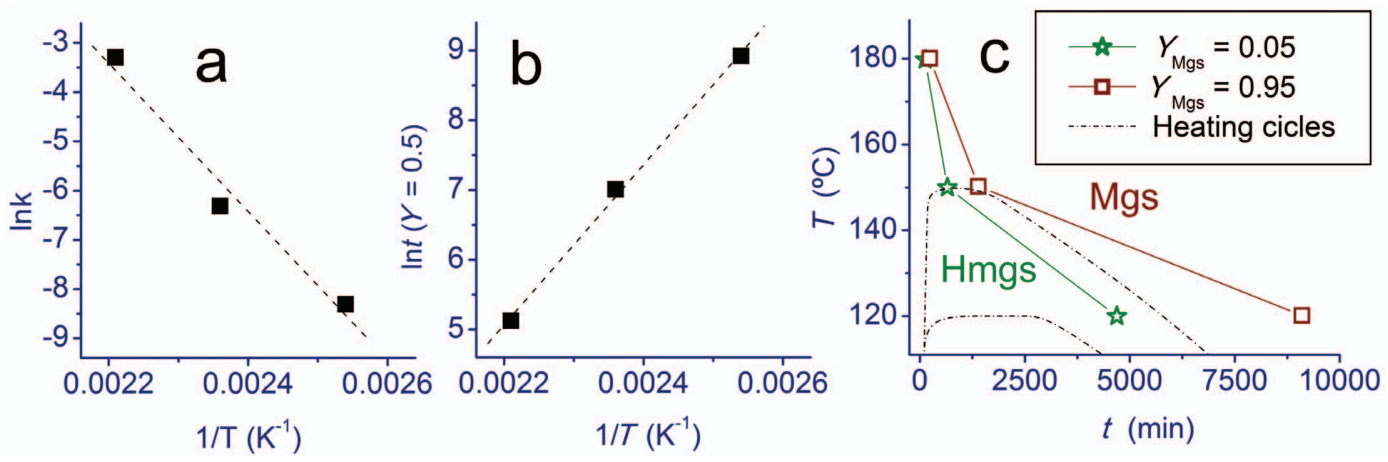

FIG. 5. (a) Linear fitting of lnk vs. the reciprocal of temperature expressed in Kelvin. (b) Linear fitting of $\ln t_{\mathrm{Y}}=0.5$ vs. the reciprocal of temperature in Kelvin. (c) TTT graph of the transformation process of hydromagnesite to magnesite. The dashed lines indicate two hypothetical heating cycles. 
pointed out, this activation energy is in some way meaningless because $\mathrm{k}$ corresponds to a combination of several rates, i.e. dissolution, masstransfer, dehydration, nucleation and growth.

The activation energy can also be calculated by the so-called method of "time to a given fraction" (Putnis, 1992). This method is based on the idea that the mole fraction of product $\left(Y_{\mathrm{Mgs}}\right)$ and the time $t$ are related by a function, $t_{Y}=\mathrm{f}(Y)$, which does not change over the temperature range studied. Therefore, $t_{Y}$ could be the dependent variable instead of $\mathrm{k}$, and therefore

$$
t_{Y}=\text { const. } \cdot e^{\left(\frac{-E_{\mathrm{a}}}{\mathrm{RT}}\right)}
$$

In practice, a linear fitting of the experimental values closer to $Y_{\mathrm{Mgs}}=0.5$ allows interpolation of the time $\left(t_{0.5}\right)$ at which half of the final moles of magnesite were precipitated. Plotting $\ln t_{0.5}$ on the ordinate $v s .1 / T$ on the abscissa, $E_{\mathrm{a}} / \mathrm{R}$ is given by the slope of the corresponding linear fitting function (Fig. 5b). Here, the "time to a given fraction method' gives a value of $93.3 \mathrm{~kJ} \cdot \mathrm{mol}^{-1}$ for the activation energy of the transformation of hydromagnesite to magnesite (see Table 4). The difference from the previous value is not surprising. In fact, this second method has the advantage of avoiding the strong dependence of the 'kinetic constant' method with respect to the function used to calculate the rate constant.

A suitable way to give kinetic information is the experimental determination of TemperatureTransformation-Time (TTT) diagrams. While TTT diagrams are commonly used in material and mineral sciences (Putnis, 1992) to deal with sub-solidus phase transformations, to our knowledge they have only been applied to coupled dissolution-crystallization processes in the case of the pseudomorphic replacement of leucite by analcime (Putnis et al., 2007). In the present study, a preliminary diagram from the experimental data compiled on Table 1 has been

TABLE 4. Summary of calculated activation energies.

\begin{tabular}{|c|c|c|}
\hline Method & $\begin{array}{c}E_{\mathrm{a}} \\
\left(\mathrm{kJ} \mathrm{mol}^{-1}\right)\end{array}$ & Error \\
\hline Rate constants & 122.6 & \pm 20 \\
\hline Time to a given fraction & 93.3 & \pm 3.3 \\
\hline
\end{tabular}

determined. The values of $t_{0.05}$ and $t_{0.95}$ corresponding to the three temperatures studied in this work were interpolated - the result is shown in Fig. $5 c$. Given that the transformation rate increases with increasing temperature, the diagrams cannot be expected to have the typical ' $\mathrm{C}$ ' shape. The shape is similar to the diagrams of transformations that take place with rising temperature. These diagrams are particularly relevant to metamorphic processes because they allow us to determine if a given transformation will take place during a heating cycle. Reaching a high temperature is not sufficient for the transformation to occur in the case of a short heating period. In contrast, the transformation can occur at lower temperatures maintained for a prolonged time. The diagram in Fig. $5 c$ could have a similar application as illustrated by the hypothetical heating cycles displayed in the graph. With this in mind, additional data for other temperatures should be obtained.

\section{Conclusions and future work}

The aim of the present study was to investigate the transformation of a hydrated magnesium carbonate phase to an anhydrous magnesium carbonate. A series of experiments at 120,150 and $180^{\circ} \mathrm{C}$ with different heating times was performed to monitor the amount of magnesite generated (and hydromagnesite removed) as a function of time. According to the experimental results, the transformation can be considered a replacement (dissolution-precipitation) process. The activation energy calculated is an estimate of the energetic barrier that hinders the transformation of hydromagnesite into the thermodynamically stable magnesite phase as established from TST theory. Future efforts will attempt to determine the lowest temperature that allow the transformation to take place, and could help to solve the problems associated with the formation of anhydrous $\mathrm{MgCO}_{3}$. Although the present results allow us to discard transformation mechanisms other than dissolution-precipitation, the coupling between both processes will be investigated further by ${ }^{18} \mathrm{O}$ isotope tracing between the aqueous solution and the precipitate (Ruiz-Agudo et al., 2014). Attempts will also be made to understand the mechanisms underlying the activation energy barrier for such a transformation and particularly the role of the masstransfer effectiveness. 


\section{Acknowledgements}

This work was supported by Marie Curie Initial Training Network "Geologic Carbon Storage" (European Commission, FP7-People-ITN-CO2REACT-317235). The authors acknowledge Dr Christine V. Putnis and two anonymous reviewers for their insightful comments which helped to make a better and clearer manuscript. They also thank the editors for their comments and suggestions.

\section{References}

Allison, J.D., Brown, D.S. and Novo-Gradac, K.J. (1991) MINTEQA2, a geochemical assessment model for environmental systems. Report EPA/600/ 3-91/0-21, U. S. Environmental Protection Agency, Athens, Georgia, USA, $107 \mathrm{pp}$.

Arvidson, R.S. and Mackenzie, F.T. (1999) The dolomite problem: Control of precipitation kinetics by temperature and saturation state. American Journal of Science, 229, 257-288.

Bénézeth, P., Saldi, G.D., Dandurand, J.L. and Schott, J. (2011) Experimental determination of the solubility product of magnesite at 50 to $200^{\circ} \mathrm{C}$. Chemical Geology, 286, 21-31.

Cardew, P.T. and Davey, R.J. (1985) The kinetics of solvent-mediated phase transformations. Proceedings of the Royal Society of London A, 398, 415-428.

Gislason, S.R. and Oelkers, E.H. (2014) Carbon storage in basalt. Science, 344, 373-374.

Hänchen, M., Prigiobbe, V., Baciocchi, R. and Mazzotti, M. (2008) Precipitation in the Mg-carbonate systemeffects of temperature and $\mathrm{CO}_{2}$ pressure. Chemical Engineering Science, 63, 1012-1028.

Jorgensen, D.G. (1989) Using geophysical logs to estimate porosity, water resistivity, and intrinsic permeability. U.S. Geological Survey Water supply Paper 2321, 24 pp.

Königsberger, E., Königsberger, L.C. and Gamsjäger, H. (1999) Low-temperature thermodynamic model for the system $\mathrm{Na}_{2} \mathrm{CO}_{3}-\mathrm{MgCO}_{3}-\mathrm{CaCO}_{3}-\mathrm{H}_{2} \mathrm{O}$. Geochimica et Cosmochimica Acta, 63, 3105-3119.

Lasaga, A.C. (1998) Kinetic Theory in the Earth Sciences. Princeton University Press, Princeton, New Jersey, USA, 811 pp.

Mackenzie, F.T. and Andersson, A.J. (2013) The marine carbon system and ocean acidification during Phanerozoic time. Geochemical Perspectives, 2, $1-227$.

Matter, J.M., Broecker, W.S., Gislason, S.R., Gunnlaugsson, E., Oelkers, E.H., Stute, M., Sigurdardóttir, H., Stefansson, A., Alfreðsson, H.A., Aradóttir, E.S., Axelsson, G., Sigfússon, B. and Wolff-Boenisch, D. (2011) The CarbFix Pilot Project - storing carbon dioxide in basalt. Energy Procedia, 4, 5579-5585.

Mullin, J.W. (2001) Crystallization, $4^{\text {th }}$ Edition. Butterworth Heineman, Oxford, UK, 594 pp.

Oelkers, E.H., Bénézeth, P. and Pokrovski, G.S. (2009) Thermodynamic database for water rock interaction. Pp. 1-46 in: Thermodynamics and Kinetics of Water-Rock Interaction (E.H. Oelkers and J. Schott, editors). Reviews in Mineralogy and Geochemistry, 70, Mineralogical Society of America and the Geochemical Society, Chantilly, Virginia, USA.

Oelkers, E.H. and Gislason, S.R. (2010) Water- $\mathrm{CO}_{2}{ }^{-}$ rock interaction during carbon sequestration. Pp. 325-344 in: Ion Partitioning in AmbientTemperature Aqueous Systems (M. Prieto and H. Stoll, editors). EMU Notes in Mineralogy, 10, European Mineralogical Union and the Mineralogical Society of Great Britain \& Ireland, London.

Parkhurst, D.L. and Appelo, C.A.J. (2013) Description of input and examples for PHREEQC version $3-A$ computer program for speciation, batch-reaction, one-dimensional transport, and inverse geochemical calculations. (http://pubs.usgs.gov/tm/06/a43) U.S. Geological Survey Techniques and Methods, book 6, chap. A43, 497 pp.

Pokrovsky, O.S. and Schott, J. (1999) Processes at the magnesium-bearing carbonates/solution interface. II. Kinetics and mechanism of magnesite dissolution. Geochimica et Cosmochimica Acta, 63, 881-897.

Pokrovsky, O.S., Schott, J. and Thomas. F. (1999) Processes at the magnesium-bearing carbonates/ solution interface. I. A surface speciation model for magnesite. Geochimica et Cosmochimica Acta, 63, 863-880.

Prieto, M., Paniagua, A. and Marcos, C. (1996) Formation of primary fluid inclusions under the influence of the hydrodynamic environment. European Journal of Mineralogy, 8, 987-996.

Prigiobbe, V. and Mazzotti, M. (2013) Precipitation of $\mathrm{Mg}$-carbonates at elevated temperature and partial pressure of $\mathrm{CO}_{2}$. Chemical Engineering Journal, 223, 755-763.

Putnis, A. (1992) Introduction to Mineral Science. Cambridge University Press, Cambridge, UK, 479 pp.

Putnis, C.V., Geisler, T., Schmid-Beurmann, P., Stephan, T. and Ciriaco, G. (2007) An experimental study of replacement of leucite by analcime. American Mineralogist, 92, 19-26.

Ruiz-Agudo, E., Putnis, C.V. and Putnis, A. (2014) Coupled dissolution and precipitation at mineralfluid interfaces. Chemical Geology, 383, 132-146.

Saldi, G.D., Jordan, G., Schott, J. and Oelkers, E.H. 
(2009) Magnesite growth rate as a function of temperature and saturation state. Geochimica et Cosmochimica Acta, 73, 5646-5657.

Sandengen, K., Jøsang, L.O. and Kaasa, B. (2008) Simple method for synthesis of magnesite $\left(\mathrm{MgCO}_{3}\right)$. Industrial and Engineering Chemistry Research, 47, $1002-1004$.

Sayles, F.L. and Fyfe, W.S. (1973) The crystallization of magnesite from aqueous solution. Geochimica et Cosmochimica Acta, 37, 87-99.

Urosevic, M., Rodriguez-Navarro, C., Putnis, C.V., Cardell, C., Putnis, A. and Ruiz-Agudo, E. (2012) In situ nanoscale observations of the dissolution of $\{10 \overline{1} 4\}$ dolomite cleavage surfaces. Geochimica et Cosmochimica Acta, 80, 1-13.

Weber, J.N. (1964) Trace element composition of dolostones and dolomites and its bearing on the dolomite problem. Geochimica et Cosmochimica Acta, 28, 1817-1868.

Wolery, T.J. (1992) EQ3/6, a software package for geochemical modeling of aqueous systems. Lawrence Livermore National Laboratory. Report UCRL-MA-110662 Pt I-III, Livermore, California, USA, $246 \mathrm{pp}$.

Xing, Z., Hao, Q., Ju, Z., Xu, L. and Qian, Y. (2010) Synthesis of $\mathrm{MgCO}_{3}$ microcrystals at $160^{\circ} \mathrm{C}$ starting from various magnesium sources. Materials Letters, 64, 1401-1403.

Xu, J., Yan, C., Zhang, F., Konishi, H., Xu, H. and Teng, H.H. (2013) Testing the cation-hydration effect on the crystallization of $\mathrm{Ca}-\mathrm{Mg}-\mathrm{CO}_{3}$ systems. Proceedings of the National Academy of Sciences of the United States of America, 110, 17750-17755. 